\title{
Nye tiltag i grammatikundervisningen
}

\begin{abstract}
The author discusses the disadvantages of traditional grammar teaching from a didactic and learning perspective. Traditional grammar teaching is typically based on a theoretical introduction by means of system-orientated grammars, followed by product-orientated training. Due to the disadvantages of traditional grammar teaching, the author suggests replacing system-orientated grammars with holistic grammars and product-orientated training with comprehension-orientated training. A holistic grammar integrates systemic and pragmatic linguistic description with a view to making grammar relevant and interesting to the learner, while comprehension-oriented training moves focus away from production and on to comprehension for the purpose of promoting learning.
\end{abstract}

\section{Indledning}

Har den traditionelle grammatikundervisning spillet fallit? Hvis formålet med grammatikundervisningen er at styre og fremme sprogindlærernes intersproglige udvikling, så de bliver stadig bedre til at formulere sig mundtligt og skriftligt på målsproget, synes svaret ja. De fleste fremmedsprogspædagoger har formentligt oplevet, at sprogindlærere, efter at et givet grammatisk emne var blevet omhyggeligt forklaret og grundigt $\emptyset$ vet, fik "tilbagefald" og begik samme fejl igen, såvel i skriftlig som i mundtlig sprogproduktion. Dette er, vil de fleste nok give mig ret i, en temmelig frustrerende oplevelse, især fordi allerede gennemgået stof så igen må forklares og trænes. Når formidlingen på denne baggrund ikke synes særlig vellykket, skyldes det formentligt følgende to forhold, der kendetegner grammatikundervisningen:

- teoretisk indføring ved hjælp af systemorienterede grammatikker

- træning ved hjælp af en produktorienteret tilgang

* Vibeke Andersen

Cand. ling. merc.; Ph.d.-studerende

Herluf Trolles Vej 315

DK-5220 Odense $S \emptyset$ 
I denne artikel vil jeg argumentere for, hvorfor ovennævnte ikke skønnes hensigtsmæssig set ud fra et indlæringsmæssigt perspektiv. I forlængelse heraf vil jeg komme med forslag til alternative tilgange, der efter min mening vil kunne forbedre grammatikundervisningen på landets uddannelsesinstitutioner. Disse beror på:

- teoretisk indføring ved hjælp af holistisk opbyggede grammatikker

- træning ved hjælp af først en forståelsesorienteret tilgang og derefter en produktorienteret tilgang

Ved 'holistisk grammatik' forstår jeg en grammatik, der både består af en systemorienteret og en pragmatisk-funktionel del. Den forståelsesorienterede tilgang er, som antydet, rettet mod forståelsen af et givet grammatisk emne og baseres på forståelsesorienterede øvelser (se afsnit 4). Da der ikke tidligere har været tradition for at anvende nævnte typer $\emptyset$ velser i grammatikundervisning på BA-studiet i spansk, besluttede min kollega Lone Ambjørn og jeg at udvikle en øvelsestypologi baseret på den forståelsesorienterede tilgang. De forståelsesorienterede $\emptyset$ velser er hovedsageligt inspireret af Ellis (1993, 1995), hvis øvelsesforslag vi kun fandt skitseret på et overordnet plan, og som vi derfor ikke umiddelbart kunne overtage.

Afslutningsvist vil jeg plædere for en videreførelse af de forståelsesorienterede $\emptyset$ velser i forbindelse med indlæring af pragmatisk-funktionelle kategorier.

\section{Systemorienteret grammatik versus holistisk grammatik}

Den systemorienterede grammatik betragter sproget som et system bestående af enkelte velafgrænsede og præcist definerede dele (strukturer), der griber ind i hinanden i et lukket kredsløb (Helm Petersen, 1992). Traditionelt defineres grammatik således som bestående af syntaks (sætninger, syntagmer) og morfologi (ord, morfemer). Sætningen er den største analyseenhed, og alt, hvad der rækker ud over denne, har ingen relevans. Ulempen ved dette grammatiksyn er, at sproget betragtes som en statisk størrelse løsrevet fra kommunikative situationer, hvorved der ses bort fra de sproglige størrelsers pragmatiske anvendelsesmuligheder i talt og skreven diskurs. Dette kan have den uheldige følgevirkning, at de grammatiske regler indlæres for deres egen skyld, og at grammatikken 
bliver et mål i sig selv. Den systemorienterede grammatik har imidlertid den fordel, at den i forbindelse med konkrete beskrivelser af grammatiske fænomener har lettere ved at opstille formalsproglige kategorier (ordklasser og funktioner), som er relativt faste og indiskutable. Eksempelvis kan det spanske subjektspronomen yo (jeg) kun benyttes om 1. person singularis, mens tú (du) og usted (De) kun kan benyttes om 2. person singularis uanset den kommunikative situation.

I den holistiske grammatik suppleres den systemorienterede tilgang med en pragmatisk-funktionel tilgang, der bevæger sig ud over sætningsniveauet og inddrager sproget i kommunikative situationer. Den pragmatisk-funktionelle tilgang i forbindelse med eksempelvis det spanske subjektspronomen yo vedrører nævnte pronomens mulige pragmatiske funktioner i relation til kommunikative situationer. Det bør her nævnes, at de spanske subjektspronomener er underforståede i verbalformernes morfologi, og at brugen af nævnte pronomener derfor ikke er obligatorisk, i modsætning til brugen af de danske subjektspronomener. Afsenders brug af yo kunne således være motiveret af dennes ønske om at signalere emfase: Yo nunca digo mentiras (Jeg lyver aldrig), mens afsenders tiltale af modtager ved hjælp af usted kunne være begrundet $\mathrm{i}$ dennes $\emptyset$ nske om at udvise verbal høflighed, respekt eller social distance.

Fordelen ved den pragmatisk-funktionelle indfaldsvinkel er, at den er mere brugsorienteret, idet den forklarer sproglige fænomener i en diskursiv og interaktionel sammenhæng. Sproget opfattes således ikke som en statisk, men dynamisk størrelse, der konstant er i bevægelse. Ulempen ved denne tilgang er imidlertid, at det rent pædagogisk kan være svært at afgrænse og definere pragmatisk-funktionelle kategorier, og at de derfor kan være vanskelige at opstille på en tilfredsstillende måde med henblik på formidling. Dette skyldes antageligt den omstændighed, at en formalsproglig størrelses pragmatiske funktioner altid beror på en fortolkning med afsæt i en given kommunikativ situation, og at nævnte størrelse i én kontekst kan have én pragmatisk funktion, mens den i en anden kontekst kan have en helt anden pragmatisk funktion. Dette kan illustreres ved hjælp af det spanske subjektspronomen usted, hvis pragmatiske funktion, som tidligere nævnt, fx kan være høflighed, respekt eller social distance. Usted kan imidlertid også benyttes med henblik på at udvise autoritet, blandt andet ved en forælders tiltale af sit barn, som han/hun normalt 
tiltaler med tú. Denne brug kan ses i forbindelse med ordrer: ;Usted se sienta ahora mismo! (Nu sætter De Dem ned!).

Som vi har set, har både den systemorienterede og den pragmatiskfunktionelle tilgang hver især fordele og ulemper, hvorfor jeg mener, at ingen af dem alene bør danne udgangspunkt for pædagogiske grammatikker, men indgå i en helhed, det vil sige i en holistisk grammatik. Det bør nævnes, at den holistiske grammatik så vidt vides ikke tidligere er set udarbejdet, men at det er mit håb, at de her skitserede tanker kan være inspirationskilde ved udarbejdelse af fremtidige grammatikker til brug inden for fremmedsprogsundervisningen.

Den holistiske grammatiks force er dens sammenkædning og beskrivelse af sprogets system og funktion ved hjælp af traditionel sætningsgrammatik (den systemorienterede tilgang) og pragmatik (den pragmatisk-funktionelle tilgang). På denne måde blive grammatikken relevant og vedkommende for sprogindlærerne, der kan relatere de formalsproglige kategorier til konkret sprogbrug i kommunikative situationer.

Jeg mener, at den holistiske grammatik bør være bundstyret, det vil sige startende med den systemorienterede del af grammatikken, hvis formalsproglige kategorier og opbygning kan overtages mere eller mindre direkte fra de traditionelle grammatikker. Efter den systemorienterede del følger den pragmatisk-funktionelle del, hvor de formalsproglige kategoriers pragmatiske funktioner beskrives. Når jeg plæderer for dette hierarki, skyldes det en antagelse om, at det set ud fra et indlæringsmæssigt perspektiv synes uhensigtsmæssigt at lære sprogindlærere, hvordan et givet sprogligt fænomen anvendes pragmatisk-funktionelt, før de har stiftet bekendtskab med de formalsproglige kategorier. Eller sagt lidt forenkelt, sprogindlærere vil formentlig have vanskeligt ved at forstå og forholde sig til eksempelvis høflighedsstrategier ved hjælp af usted eller verbalformer i konjunktiv og condicional, hvis de ikke er bekendte med de spanske subjektspronomener eller spanske verbers bøjningsformer.

Som tidligere nævnt mener jeg, at den systemorienterede del i den holistiske grammatik kan baseres på traditionelle grammatikkers beskrivelse af de formalsproglige kategorier. Den holistiske grammatiks pragmatisk-funktionelle del bør imidlertid have det pragmatiske begrebsapparat som overordnet ramme, og det ville således være hensigtsmæssigt at begynde denne del med en introduktion til pragmatikken samt diverse relevante pragmatiske aspekter såsom sproghandlinger (sml. 
'speech acts'), selvbillede (sml. 'face'), illokutionær pointe (sproghandlingens artsbestemte formål) og den kommunikative situations sociale aspekter (rolle-, styrke- og distanceforholdet afsender og modtager imellem). Efter nævnte introduktion bør følge en beskrivelse af de formalsproglige kategoriers mulige pragmatiske funktioner. Beskrivelserne kan struktureres i særskilte afsnit og med omhyggelig reference til den pågældende formalsproglige kategori i den systemorienterede del. Det skal indskydes, at jeg ikke mener, at alle formalsproglige kategorier kan eller bør anskues ud fra en pragmatisk-funktionel tilgang. Eksempelvis vil præpositioner formentlig sjældent, hvis overhovedet, optræde med et decideret pragmatisk sigte på grund af deres neutrale semantiske betydning. Formalsproglige kategorier, der med fordel kunne beskrives i den holistiske grammatiks pragmatisk-funktionelle del, kunne være subjektspronomener, demonstrative pronomener og interrogative pronomener, der henviser til en given person, de såkaldte persondeiktiske udtryk. De persondeiktiske udtryk udgør en central rolle i mit ph.d.-projekt, hvor jeg har undersøgt udtrykkenes mulige pragmatiske funktioner i hverdagsrelaterede spanske dialoger. Mine iagttagelser har vist, at de persondeiktiske udtryk kan have forskellige pragmatiske funktioner, som kan beskrives og kategoriseres under diverse betegnelser. Denne, så vidt vides, første empirisk baserede kategorisering af de spanske persondeiktiske udtryks pragmatiske funktioner kunne overføres til den holistiske grammatiks pragmatisk-funktionelle del. Jeg erkender, at dette kun er et første skridt henimod en opbygning af en grammatik efter det holistiske princip, og at der er tale om begrænsede formalsproglige kategoriers pragmatiske funktioner. Det er imidlertid mit håb, at udarbejdelser eller videreudviklinger af kategoriseringer i forbindelse med andre formalsproglige størrelsers pragmatiske funktioner vil kunne bidrage til en udbygning af den holistiske grammatiks pragmatisk-funktionelle del.

Jeg vender tilbage til de persondeiktiske udtryks pragmatiske funktioner i forbindelse med en skitsering af de forståelsesorienterede øvelser $i$ afsnit 4. En forståelse af de principper, der ligger til grund for nævnte $\emptyset$ velser nødvendiggør imidlertid et indblik i den forståelsesorienterede tilgang, der beskrives i næste afsnit sammen med den produktorienterede tilgang. 


\section{Produktorienteret tilgang versus forståelsesorienteret tilgang}

I det følgende skitseres grundprincippet i den produkt- og forståelsesorienterede tilgang ${ }^{1}$

Ifølge den produktorienterede tilgang trænes et grammatisk emne umiddelbart efter bevidstgørelsesfasen (den teoretiske gennemgang af et grammatisk emne) ved hjælp af gentagen produktiv praksis med det formål at påvirke output (det sprog sprogindlærere producerer i skrift og tale). Gennem nævnte metode formodes den eksplicitte (bevidste) kontrollerede viden om en given grammatisk struktur at blive konverteret til implicit, automatiseret viden, det vil sige en ubesværet og ureflekteret brug af strukturen. Metoden forudsætter, at sprogindlærere umiddelbart efter bevidstgørelsesfasen er i stand til at producere korrekt fremmedsprog. Denne forudsætning skaber ifølge forskere inden for psykolingvistikken indlæringsmæssige problemer, fordi den menneskelige hjerne kun er i besiddelse af en begrænset evne til at forarbejde og tilegne sig nye informationer (Ellis 1993, 1995). Ifølge disse forskere skyldes de indlæringsmæssige problemer, at sprogindlærerne på et for tidligt niveau i indlæringsprocessen sættes til at producere sprog, før de er parate til at optage nye elementer i fremmedsproget.

Den forståelsesorienterede tilgang flytter, på baggrund af de ovenfor beskrevne svagheder ved den produktorienterede tilgang, fokus væk fra produktion til forståelse umiddelbart efter bevidstgørelsesfasen. Målet med den forståelsesorienterede tilgang er således at optimere inputbearbejdningen ${ }^{2}$ og dermed fremme intake (hvad sprogindlæreren forstår af input, men ikke nødvendigvis er i stand til at bruge i praksis). Den forstå-

\footnotetext{
${ }^{1}$ For yderligere uddybning henvises til Ambjørns (1998) artikel i Sprogforum nr. 10 (se under referencer).

2 Der findes to modeller for inputbearbejdning, der har bevidstgørelse som fællesnævner.

Den ene repræsenteres blandt andet af Cadierno/Vanpatten (1993, 1994) og tager udgangspunkt i strukturerede input i form af læse- og lytteopgaver, der fokuserer på en given sproglig struktur. Hensigten med denne fokusering er at hjælpe sprogindlærerne til at danne relationer mellem form og betydning, hvilket skulle påvirke både input og output. Denne model tildeler ikke grammatikundervisningen nogen særlig rolle i sprogtilegnelsesprocessen.

Den anden model repræsenteres af Ellis $(1993,1995)$. Til forskel fra Cadierno/Vanpatten omfatter det fokuserede input i denne model eksplicit undervisning i grammatiske regler. Herudover er Ellis uenig med Cadiernos/Vanpattens opfattelse af, at fokuserede
} 
elseorienterede tilgang tager højde for den menneskelige hjernes begrænsede forarbejdnings- og tilegnelseskapacitet og fokuserer på aktiviteter, der hjælper sprogindlæreren til at effektivisere inputforarbejdningen. Det primære mål ved nævnte tilgang er således fokus på input rettet mod forståelsen. Først på det næste trin rettes opmærksomheden mod produktion og output $\mathrm{i}$ en progression gående fra bundne til frie produktive $\emptyset$ velser. Det kan sammenfattende siges, at den forståelsesorienterede tilgangs force er, at den tager selve processen i sprogindlæringen i betragtning.

\section{Forståelsesorienterede øvelser}

Den forståelsesorienterede tilgang kan, som tidligere beskrevet, baseres på forståelsesorienterede øvelser, der sættes ind før de produktive $\emptyset$ velser. Formålet med de forståelsesorienterede $\emptyset$ velser er at fremme sprogindlærerens forståelse, hvorfor der ikke her lægges op til nogen form for produktion på fremmedsproget. Sproglig produktion sker først på det næste trin i forbindelse med de produktorienterede $\emptyset$ velser i automatiseringsfasen med henblik på at konvertere den eksplicitte viden til implicit viden. Jeg mener imidlertid, at man for at opnå den fulde implicitte viden også er nødt til at anskue grammatik i et pragmatisk-funktionelt perspektiv, hvor grammatikken præsenteres i en kontekst og forankret $\mathrm{i}$ kommunikative situationer. De forståelsesorienterede $\emptyset$ velser, der anvendes $\mathrm{i}$ forbindelse med grammatikundervisningen på BA-studiet $\mathrm{i}$ spansk på HHÅ, er udarbejdet til brug i forbindelse med den traditionelle pædagogiske grammatik. Det er imidlertid min overbevisning, at princippet i de forståelsesorienterede øvelser også vil kunne anvendes i forbindelse med eksempelvis de persondeiktiske udtryks pragmatiske funktioner. I denne sammenhæng er det nødvendigt at udvikle forståelsesorienterede $\emptyset$ velser, der, som et led i bevidstgørelsesfasen, skal fokusere på sprogindlærernes forståelse af brugsaspektet ved de persondeiktiske udtryk. Efter denne fase kan anvendes bundne og frie produktive

input også kan påvirke output. I stedet plæderer han for en model, hvor træning først rettes mod forståelse af sproglige fænomener med henblik på at påvirke input, og dernæst mod sproglig produktion med henblik på at påvirke output. Grundprincippet i nævnte model har givet inspiration til benævnelsen 'den forståelsesorienterede tilgang', der ligger til grund for de 'forståelsesorienterede øvelser'. 
$\emptyset$ velser, der, som et led i automatiseringsfasen, skal udvikle den implicitte viden. Nedenfor vil jeg forsøge at konkretisere den beskrevne progression med udgangspunkt i de persondeiktiske udtryk. Det bør nævnes, at de forståelsesorienterede $\emptyset$ velser og den foreslåede progression formentlig vil kunne anvendes i forbindelse med en række andre formalsproglige kategorier end de persondeiktiske udtryk og i en hvilken som helst undervisningsmæssig sammenhæng, idet det i princippet kun er fantasien, der sætter grænser for $\varnothing$ velsernes anvendelsesmuligheder.

Inden den egentlige anvendelse af de forståelsesorienterede $\emptyset$ velser introduceres sprogindlærerne for det pragmatiske begrebsapparat og de persondeiktiske udtryks pragmatiske anvendelsesmuligheder, som bør beskrives i starten af den pragmatisk-funktionelle del i den holistiske grammatik. Efter den teoretiske introduktion til de nævnte genstandsområder præsenteres sprogindlærerne for de forståelsesorienterede $\emptyset$ velser, der kan inddeles i følgende tre faser:

\section{Fase 1: Øvelser der understøtter forståelsen af den gennemgåede teori, fx ved hjælp af}

- spørgsmål til det pragmatiske begrebsapparat

- identifikation af forekommende persondeiktiske udtryk i forskellige sproghandlinger

- systematisering af udvalgte persondeiktiske udtryks pragmatiske funktioner i forskellige sproghandlinger

\section{Fase 2: Bundne produktive øvelser}

Fx indsættelse af et persondeiktisk udtryk, der

- fremhæver modtagers rolle i det pågældende sagsforhold

- nedtoner afsenders rolle i det pågældende sagsforhold

\section{Fase 3: Frie produktive øvelser}

- Fx opbygning af en dialog mellem A (far) og B (søn), hvori indgår persondeiktiske udtryk, der fremmer sønnens kommunikative mål (fx at få faderen til at købe sig en cykel)

- Fx opbygning af en dialog mellem A (kammerat) og B (kammerat), hvori indgår persondeiktiske udtryk, der nedtoner den potentielle truslen mod B's selvbillede i forbindelse med en bebrejdelse. 


\section{Afsluttende bemærkninger}

I denne artikel har jeg givet forslag til, hvordan grammatikundervisningen kan ændres med henblik på at forbedre sprogindlæreres sproglige output. Denne ændring kan ske ved at gå bort fra systemorienterede grammatikker og en produktorienteret tilgang og ved i stedet at anvende holistiske grammatikker, bestående af en systemorienteret og en pragmatisk-funktionel del, samt en forståelsesorienteret tilgang. Fordelen ved den holistiske grammatik er, at den både beskriver de formalsproglige kategorier og deres praktiske anvendelse i kommunikative situationer, hvorved grammatikken bliver relevant og vedkommende for sprogindlærerne. Fordelen ved en forståelsesorienteret tilgang er, at den flytter fokus væk fra det sproglige output og over på indlærings- og tilegnelsesprocessen med det formål at fremme indlæringen hos sprogindlæreren.

\section{Referencer}

Ambjørn, Lone (1998). Reception før produktion - proces før produkt In Sprogforum nr. $10,50-55$.

Cadierno, Teresa (1994). On the role of instruction in SLA: Research results and theoretical explanations. In Pluridicta 29.

Cadierno, Teresa \& Bill Vanpatten (1993). SLA as input processing: A role for instruction. In Studies in Second Language Acquisition, 18, 495-510.

Ellis, Rod (1993a). Interpretation-based grammar teaching. In System, 21/1, 66-78.

Ellis, Rod (1993b). The structural syllabus and second language acquisition. In Tesol Quarterly, 27/1, 91-113.

Ellis, Rod (1995). Interpretation tasks for grammar teaching. In Tesol Quarterly, 29/1, 87-105.

Petersen, Uwe Helm (1992).Grammatik i fremmedsprogsundervisningen. In Kasper, Gabriele/Wagner, Johannes. Grundbog i Fremmedsprogspaedagogik, 213-224. 
